\title{
Venture Capital Participation and Post-IPO Performance, an Empirical Research on Companies Listed in China
}

\author{
Tao Li ${ }^{1}$, Fang Zhang ${ }^{1,2}$, Hao Liu ${ }^{1}$ and Tianle Zhai ${ }^{3, *}$ \\ ${ }^{1}$ School of Economics and Management, North China Electric Power University, \\ Beijing, China \\ ${ }^{2}$ State Tobacco Monopoly Administration, Beijing, China \\ ${ }^{3}$ School of Electrical Engineering, Zhengzhou University, Zhengzhou, China \\ *13811522015@163.com
}

\begin{abstract}
Extensive studies from American and some European stock markets have pointed out that venture capital (VC) has a constructive influence on sustainable developments of their invested companies. In this paper, RBF neural network, principal component analysis, and mean variance analysis are functional and well utilized to test the effects of $V C s$ on enterprises' post-IPO performances in China. The empirical results indicate that venture capitals in China brought undesirable effects to both operating performance and market performance, but performed well in controlling harmful volatility. Therefore, we believe VC in China has a certain positive external but not internal influence on sustainable developments of their invested companies.
\end{abstract}

Keywords: venture capital, sustainable development, operating performance, market performance, share price volatility

\section{Introduction}

Sustainable development and social contribution of a company are considered as a decision-making strategy by all stakeholders (i.e. shareholders, managers, employees, suppliers, customers, and governments) from the local to the global level, they are also what the stakeholders eventually look forward. As a sponsor of capital, a tutor of business and a supporter of commercial channels, venture capitalists have cultivated numerous successful enterprises and have created countless wealth through IPOs (Initial Public Offerings) of their invested start-ups. Meanwhile, on behalf of developing countries, China is experiencing a relatively high speed progress and having a superior economic status which forecasts the future of other developing countries. From 2005 to 2010, with a 300 times climbing, venture capitals have increased from 86.55 million US dollar to 28.13 billion US dollar in China. And half of the investments are from domestic investors [1]. Therefore, studying the effects of venture capital in China not only provide companies suggestions about attracting and bringing $\mathrm{VCs}$ in or not, but also contribute to sustainable developments of these companies and good development of developing countries' businesses. Especially, due to several factors including a relatively late start of the stock market and an even much shorter history of venture capital, studies on VC effects in China can merely be seen.

For these reasons, this article attempts to contribute to Chinese venture capital researches by covering major issues between $\mathrm{VC}$ and business aftermarket, and further contributes to the sustainable development of listed companies from China and other developing countries. Besides, researches on post-IPO performance have

* Corresponding Author 
been overstressed on the importance of profitability for the past few years, but rarely have studies worked on assessing the risk of investing in VC-backed businesses so far. Therefore, this paper introduces volatility of share prices to evaluate risks of investing in sample companies. Research on risk of investing a kind of company is not only beneficial to investors optimizing portfolios, but also providing an awareness and opportunity to companies in China. Stocks with a promising return for a lower risk are extraordinarily popular all the time in the capital market. With an excellent performance of the share price, it would be easier to attract shareholders who will tremendously promote an enterprise's sustainable development with their reputations, industrial resources and horizons of developments.

In this paper, Chinese listed companies which initiated their IPOs from 2008 to 2010 are grouped as VC-backed companies and non VC-backed companies [2]. And three representative and meaningful aspects evaluating enterprises' post-IPO performances will be compared between these two groups. They are Operating Performance, Market Performance, and Share Price Volatility.

Evaluations of operating performance and market performance are of great importance to verify the influence of venture capital. With fiscal data of the year of 2013 from listed companies that have initiated their IPOs from 2008 to 2010, we elaborately selected and adjusted five financial indicators that comprehensively represent operating performance and market performance of a company.

These indicators, however, are artificially selected. For ensuring the rationality and reliability of these indicators, and the accuracy and validity of data from databases will be presented later, we employ RBFNN (radial basis function neural network) at the very start.

After the verification of data, these five indicators are officially confirmed to demonstrate the operating performance and market performance which are the principal components (PCs) analyzed in this paper. Following RBFNN, PCA (principal component analysis) is utilized to analyze the internal relations between indicators and PCs of different groups of companies [3]. With PCA, we first classify these five indicators into two groups respectively represent operating performance and market performance. What's more, results of this analysis are apparently exhibited in two coordinates and tell the discrepancies of performances between VC- and non VC-backed companies visually.

At this point, influences of venture capital on both operating performance and market performance have been intensively studied. The last but not least, this paper is about to focus on the volatility of share prices which indicates the risk of investing in a group of enterprises. This part bridges in the gap and corrects the performance measurement by introducing the portfolio optimization instead of simply testing the difference on returns. Expanding this research beyond the scope of purely concentrating on profitability to analyze the risk of investing in a business can be concerned as an original and practical contribution of this article.

\section{Material}

\subsection{Data}

This research only studies the "real" Chinese IPOs initiated between 2008 and 2010 in Chinese two major stock exchanges, respectively, SHANGHAI STOCK EXCHANGE (SSE) and SHENZHEN STOCK EXCHANGE (SZSE), which means this article does not account for the companies as the remarketing, secondary offering and overseas public offering. The sample data were collected from different sources, including the CCER database, SSE and SZSE. 
2.1.1 Data at Time of IPO: Data at the time of the IPO were mainly collected from CCER database, including industry category, date of the IPO and top 10 shareholders of sample companies. To ensure data integrity, all data have been checked with the information provided by SSE and SZSE.

From 2006 to 2010, there are almost 700 companies that have initiated their IPOs in the two major stock exchanges of China. Adhering to previous studies, companies in financial industries such as commercial banks, insurance companies and security companies are exempt from this analysis because their criteria of financial statements are much more complex and different from general industries [4-5].

Table 1 illustrates the trend of venture capitals developed in Chinese stock markets from 2006 to 2010. According to the data, proportion of VC-backed companies was less than $30 \%$ until the year of 2008 which is applied as the beginning of time interval in this research. Therefore, for a more effective and persuasive result of this analysis, the years of 2008 to 2010 whose percentages of VC-backed companies have exceeded $30 \%$ are selected eventually. As a consequence, there are 516 companies consisted of 280 non VC-backed companies and 236 VC-backed companies listing in SSE and SZSE have been selected as sample companies.

Table 1. Distribution of VC- and Non VC-Backed IPOs from 2006 to 2010

\begin{tabular}{cccccc}
\hline & 2006 & 2007 & 2008 & 2009 & 2010 \\
\hline \multirow{2}{*}{$\begin{array}{c}\text { Non VC-backed } \\
\text { companies }\end{array}$} & 49 & 84 & 46 & 64 & 170 \\
\cline { 2 - 6 } & $(77.78 \%)$ & $(72.41 \%)$ & $(59.74 \%)$ & $(66.67 \%)$ & $(49.56 \%)$ \\
\hline \multirow{2}{*}{$\begin{array}{l}\text { VC-backed } \\
\text { companies }\end{array}$} & 14 & 32 & 31 & 32 & 173 \\
\hline \multirow{2}{*}{ All } & $(22.22 \%)$ & $(27.59 \%)$ & $(40.26 \%)$ & $(33.33 \%)$ & $(50.44 \%)$ \\
\cline { 2 - 6 } & $(100.00 \%)$ & 116 & 77 & 96 & 343 \\
\hline
\end{tabular}

Source from: CCER, Manually calculated

The brief history of venture capital in Chinese security markets is ineluctable; it imposes restrictions on the amount of IPOs with venture capital background. Barely $45 \%$ of stocks listed in the markets are VC-backed during the period from 2008 to 2010.

Moreover, it is worth noting that because of two times of IPO-suspension between the year of 2005 and 2009, the amount of IPOs initiated from 2006 to 2009 was fluctuant. Also, a global economic downturn from 2008 was one of contributory causes. However, the percentage of VC-backed companies demonstrates a growing tendency in general, which affords strong evidence on the benign development of venture capital in China.

For a large portion of early venture capital associations, they mainly focused on venture firms in the seed stage. Experiencing several years' development, a number of venture capital institutions undertake the investment in mature firms as well. Additionally, the development of the Growth Enterprise Market and the Small and Median Sized Firms Markets in SZSE keep weakening the barriers for companies listing from a great extent. 
Table 2. Industrial Distribution of VC- and Non VC-Backed IPOs between 2008 and 2010

\begin{tabular}{|c|c|c|c|}
\hline & VC-backed & non VC-backed & Total \\
\hline \multirow{2}{*}{$\begin{array}{l}\text { Agriculture, Forestry, Husbandry and } \\
\text { Fishery }\end{array}$} & 3 & 9 & 12 \\
\hline & $(1.27 \%)$ & $(3.21 \%)$ & $(2.33 \%)$ \\
\hline \multirow{2}{*}{ Extractive Industry } & 3 & 5 & 8 \\
\hline & $(1.27 \%)$ & $(1.79 \%)$ & $(1.55 \%)$ \\
\hline \multirow{2}{*}{ Manufacturing Industry } & 164 & 202 & 366 \\
\hline & $(69.49 \%)$ & $(72.14 \%)$ & $(70.93 \%)$ \\
\hline \multirow{2}{*}{$\begin{array}{l}\text { Electric Power, Gas and Hydraulic } \\
\text { Production and Supply Industry }\end{array}$} & 5 & 0 & 5 \\
\hline & $(2.12 \%)$ & $(0.00 \%)$ & $(0.97 \%)$ \\
\hline \multirow{2}{*}{ Construction Industry } & 6 & 5 & 11 \\
\hline & $(2.54 \%)$ & $(1.79 \%)$ & $(2.13 \%)$ \\
\hline \multirow{2}{*}{ Transportation and Warehousing Industry } & 5 & 5 & 10 \\
\hline & $(2.12 \%)$ & $(1.79 \%)$ & $(1.94 \%)$ \\
\hline \multirow{2}{*}{ Information Technology Industry } & 30 & 36 & 66 \\
\hline & $(12.71 \%)$ & $(12.86 \%)$ & $(12.79 \%)$ \\
\hline \multirow{2}{*}{ Wholesale and Retail Trade } & 7 & 7 & 14 \\
\hline & $(2.97 \%)$ & $(2.50 \%)$ & $(2.71 \%)$ \\
\hline \multirow{2}{*}{ Real Estate } & 3 & 1 & 4 \\
\hline & $(1.27 \%)$ & $(0.36 \%)$ & $(0.78 \%)$ \\
\hline \multirow{2}{*}{ Social Services } & 3 & 9 & 12 \\
\hline & $(1.27 \%)$ & $(3.21 \%)$ & $(2.33 \%)$ \\
\hline \multirow{2}{*}{ Communication and Cultural Industry } & 7 & 1 & 8 \\
\hline & $(2.97 \%)$ & $(0.36 \%)$ & $(1.55 \%)$ \\
\hline \multirow{2}{*}{ All } & 236 & 280 & 516 \\
\hline & $(100.00 \%)$ & $(100.00 \%)$ & $(100.00 \%)$ \\
\hline
\end{tabular}

Source from: CCER, Manually calculated

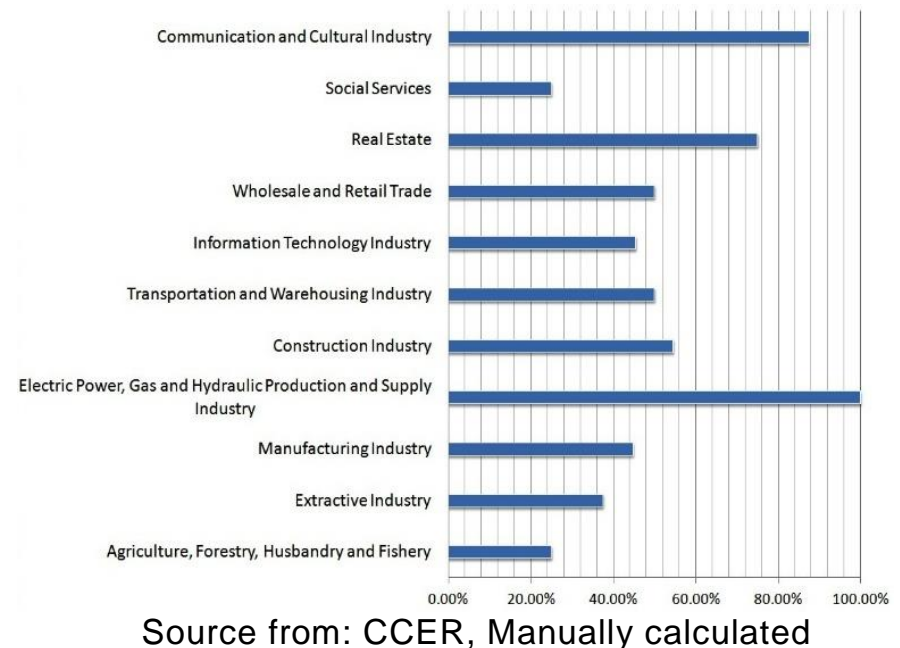

Figure 1. Percentage of VC-Backed Companies in Different Industries from 2008 to 2010

The descriptive statistics in Table 2 illustrate the industrial distribution of IPOs from the year of 2008 to 2010 . This industry classification standard is complied with the standard formulated by the China Securities Regulatory Commission. During 
these three years, the number of IPOs in the manufacturing industry has contributed around $70 \%$ of the IPOs, so has the population proportion. It explicitly tells the characteristic of Chinese industrial structure. In addition, in terms of IT industry, it demonstrates an impressed importance by occupying more than $12 \%$ and the second place in total, which also confirmed the rapid development of IT industry.

From another perspective, revealing the percentage of VC-backed companies in diverse industries, Figure 1 tells the preference of venture capital. All of the enterprises of electric power, gas and hydraulic production and supply industry were supposed by venture capitalists. Besides, the ratio of communication and cultural industry is almost 90\%, which is pursued by real estate with 75\%. Apparently, industries including public resources, culture and media, and real estate are of dramatic profitability in China and attract huge investment all the time. As a consequence, it is understandable why these industries are on such a high proportion of $\mathrm{VC}$ investment. However, because of the small amount of the IPOs in these industries above, it is undeniable and inevitable that the high percentage is of occasionality to some extent.

In addition, there are still five more industries whose proportion of VC-backed companies are over 40\%. They are Wholesale and Retail Trade, Information Technology, Transportation and Warehousing, Construction, and Manufacture.

2.1.2. Data on Aftermarket Stage: Data on aftermarket stage were mainly collected from CCER database, including daily share prices and fiscal data for acquiring financial indicators of sample enterprises. Still, all data have been checked with information from SSE and SZSE for integrity.

As previously stated, two of core researching aspects of this paper are focusing on sample companies' operating performance and market performance. For this part, we designated fiscal data from 2013 financial statements to calculate designed indicators and then evaluate sample companies. Samples are the enterprises that have initiated their IPOs between 2008 and 2010. Most VC-backed companies in their 3rd to 6th year are still under the influence of venture capitalists but also have developed their own ideas of operation and management. Furthermore, choosing latest annual financial statements is the guarantee of this paper's timeliness.

As to market risk analysis of a company, research on volatility is much more critical in this paper. A satisfactory change of the stock price does not only benefit the shareholders, but also contribute to a long-term development of the company itself. Therefore, to examine whether companies with venture capitals are under a lower risk for a certain return, or earn more profits for a specific risk, we employed closing prices from the dates of every sample company's IPO to their 700th trading day continuously. These 700 continuous trading days exactly make up 3 continuous civil years.

\subsection{Introduction of Financial Indicators}

As introduced in the previous chapter, five financial indicators are selected and adjusted to analyze the differences of operating performance and market performance between VC- and non VC-backed enterprises. They are OROA (operating return on assets), OCFROA (operating cash flow return on assets), Sample Q, WR (market wealth relative) and MC (Market Capitalization).

2.2.1. OROA and OCFROA: OROA and OCFROA are used to evaluate a company's operating profitability and cash generating capability respectively. It is noteworthy that operating profit is an indicator eliminating the influence of interests which weakens the operating profitability. Moreover, it is of equal importance to avoid tax effects caused by different enterprises' regions in this research. As the entire sample 
companies are China based and also listed in Chinese stock markets, impact of tax incentives for key supported industries and high-tech industries is necessary to be cleared up. What's more, tax refund varies with specific projects sometimes. Therefore, OROA and OCFROA are designed on pre-interest and pre-tax basis in order to remove these harmful impacts.

Here, OROA is utilized to evaluate the operating profitability of the firms. It is intended to be calculated as the sum of operating profit and interests divided by total assets.

OROA $=($ Operating Profit + Interests $) /$ Total Assets

Accordingly, OCFROA is generally adopted in order to test firm's cash generating capability in its daily business operation. It is described as net operating cash flow divided by total assets. The net operating cash flow here is adopted from CCER cash flow database.

OCFROA $=$ Net Operating Cash Flow/Total Assets

2.2.2. Tobin's Q and Sample Q: According to Lindenberg and Ross (1981), Lang et. al (1989), Tobin's Q can be a proxy to evaluate a firm's equity market performance correctly and suitably, which also has been hired in numerous researches for decades [6-7]. In this case, data of Tobin's Q can be acquired in CCER Primary Market Database. Nevertheless, the evaluation of a firm's replacement or reproduction cost is full of subjectivity and diversity from diverse agencies and assessment methods. Therefore, we abandoned Tobin's Q but employed an alternative method which can objectively assess the market performance of an enterprise. Learning the idea from Tobin's Q, this indicator is referred as "Sample Q" [8], and calculated as market value of equity plus book value of liabilities, and then divided by book value of total assets. The function is as follows:

Sample_Q $=($ MV(Equity $)+$ BV(Liabilities) $) /$ BV(Assets $)$

As observed in the function of Sample Q, the introduction of equity market value is integrated with market expectation which implies future growth opportunities. Moreover, the book values of liabilities and assets are in charge of operating performance eventually.

In the next section, it is about to introduce indicators mainly standing for market performance, they are WR and MC.

2.2.3. WR and MC: WR (market wealth relative) is built on the BHRs (buy and hold returns) method. Based on the researches dominated by Ritter (1991) and Brav and Gompers (1997), WR is a widely accepted method to demonstrate the difference of BHRs among different groups [9-10]. And it is defined as a company's BHRs divided by the BHRs of the stock market. The function is as follows:

$\mathrm{WR}=\left(1+\mathrm{BHR}_{\mathrm{i}}\right) /\left(1+\mathrm{BHR}_{\mathrm{m}}\right)$

Where BHRi indicates a firm's BHRs; BHRm represents the market BHRs.

Next, compare the final outcome with 1 . If the value of WR exceeds 1 , it means the company outperforms the overall market performance. If not, the conclusion will be opposite.

MC (market capitalization) is the total value of outstanding shares. It emerges the expectation of investors, and reveals the scale and performance of an enterprise in the capital market. 


\section{Methodology and Empirical Analysis}

We have selected and adjusted five financial indicators with fiscal data of 2013 from listed companies that have initiated their IPOs during 2008 to 2010. These indicators include OROA $\left(\mathrm{x}_{1}\right)$, OCFROA $\left(\mathrm{x}_{2}\right)$, Sample_Q $\left(\mathrm{x}_{3}\right), \mathrm{WR}\left(\mathrm{x}_{4}\right)$, and MC $\left(\mathrm{x}_{5}\right)$. Also, sample companies are divided into VC- and non VC-backed companies on the basis of CCER shareholder database.

The confirmation of the existence of performance differences between these two groups is of priority. Therefore, we employ RBFNN to verify the rationality and reliability of indicators and the accuracy and validity of data at first.

\subsection{Rationality Test of Indicators and Data}

In this paper, the performance evaluation system of sample companies consists of two first class indicators composed by five second class indicators (Table 3).

Table 3. Performance Evaluation System

\begin{tabular}{lll}
\hline & First Class Indicators & \multicolumn{1}{c}{ Second Class Indicators } \\
\hline & & OROA \\
\cline { 2 - 2 } Performance & Operating Performance & OCFROA \\
\cline { 2 - 2 } Evaluation System & & Sample Q \\
\cline { 2 - 3 } & Market Performance & WR \\
& & \\
\hline
\end{tabular}

For verifying the rationality and reliability of these five indicators and the accuracy and validity of data, RBF classifier is employed.

Data of the 516 companies in the sample set consist of the same amount of datasets. In this case, these sets are randomly classified into training set, validation set and test set by $70 \%, 15 \%$, and $15 \%$ respectively. In the process of the test, data in the training set are presented to the network during training and used to learn and fit the parameters of the classifier in the MLP (Multilayer Perceptron) case [11]. It is utilized to find the optimal weights. Data in the validation set are used to tune the parameters and find the optimal number of hidden units or determine a stopping point for the back-propagation algorithm. Data in the test set have no effect on training and so provide an independent measure of network performance during and after training. It is used only to assess the performance of a fully-trained classifier in the MLP case [12-13].

According to the result of the confusion matrixes, the integrated accuracy of indicators selection is $93.8 \%$ which has met a stringent specification (Figure 2). Also, distribution of samples with different levels of errors shows that most samples are sitting in the errors around $-2.63 \%$. Therefore, working with the confusion matrixes, rationality of these five indicators has been successfully verified (Figure $3)$. 

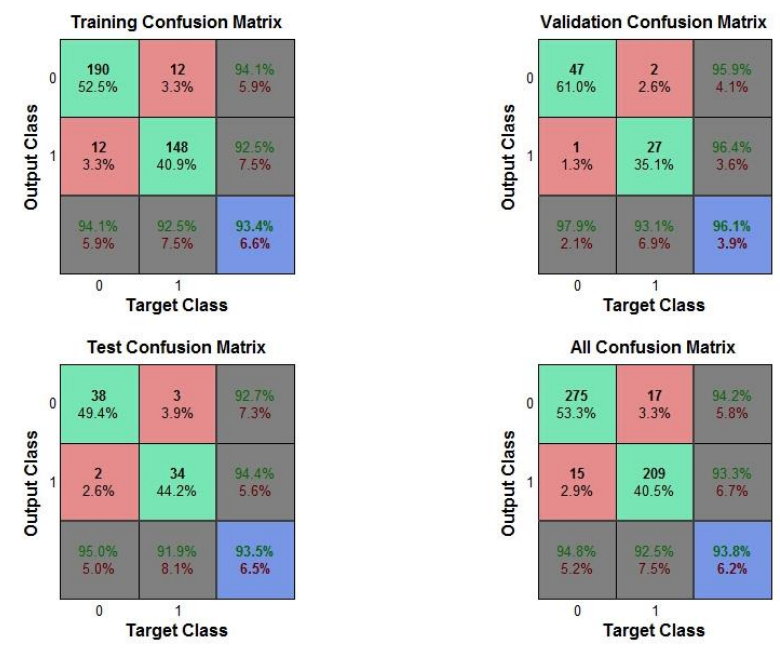

Figure 2. Confusion Matrixes of Sample Data

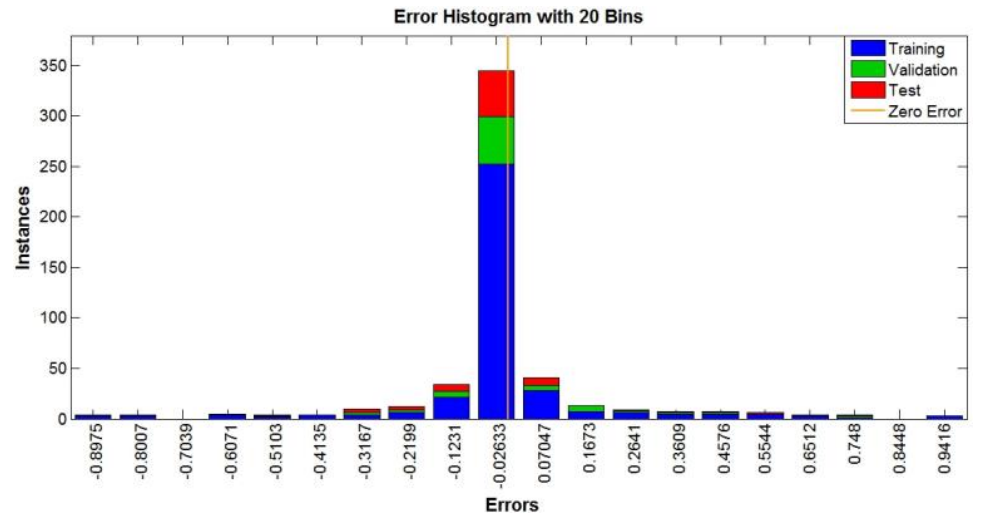

Figure 3. Error Histogram of RBF Model

Table 4. The Principal Components, Eigenvalues and Eigenvectors Satisfying PCA

\begin{tabular}{cccccc}
\hline $\begin{array}{c}\text { Variables } \\
\text { (Indicators) }\end{array}$ & $\begin{array}{c}1 \text { st PC } \\
\left(\boldsymbol{y}_{\mathbf{1}}\right)\end{array}$ & $\begin{array}{c}\text { 2nd PC } \\
\left(\boldsymbol{y}_{\mathbf{2}}\right)\end{array}$ & $\begin{array}{c}\text { 3rd PC } \\
\left(\boldsymbol{y}_{\mathbf{3}}\right)\end{array}$ & $\begin{array}{c}\text { 4th PC } \\
\left(\boldsymbol{y}_{\mathbf{4}}\right)\end{array}$ & $\begin{array}{c}5 \text { th PC } \\
\left(\boldsymbol{y}_{\mathbf{5}}\right)\end{array}$ \\
\hline $\mathbf{x}_{\mathbf{1}}$ & 0.560 & -0.131 & -0.034 & -0.428 & -0.697 \\
$\mathbf{x}_{\mathbf{2}}$ & 0.460 & -0.358 & -0.066 & 0.808 & -0.056 \\
$\mathbf{x}_{\mathbf{3}}$ & 0.555 & -0.222 & -0.014 & -0.367 & 0.713 \\
$\mathbf{x}_{\mathbf{4}}$ & 0.264 & 0.690 & -0.664 & 0.104 & 0.050 \\
$\mathbf{x}_{\mathbf{5}}$ & 0.313 & 0.574 & 0.744 & 0.139 & 0.022 \\
$\boldsymbol{\lambda}$ & 1.907 & 1.034 & 0.830 & 0.702 & 0.526 \\
$\boldsymbol{\alpha}_{\mathbf{i}}$ & 0.38139 & 0.20685 & 0.16604 & 0.14045 & 0.10527 \\
$\sum_{\mathrm{i}=1}^{\mathrm{m}} \alpha_{\mathrm{i}}$ & 0.38139 & 0.58824 & 0.75428 & 0.89473 & 1.00000 \\
\hline
\end{tabular}

\subsection{PCA of Listed Enterprises' Performances}

In this case, we have designed five financial indicators by calculating fiscal data of 2013 from listed companies that initiated their IPOs from 2008 to 2010, including OROA $\left(\mathrm{x}_{1}\right)$, OCFROA $\left(\mathrm{x}_{2}\right)$, Sample_Q $\left(\mathrm{x}_{3}\right), \mathrm{WR}\left(\mathrm{x}_{4}\right)$, and MC $\left(\mathrm{x}_{5}\right)$. Depending on the approach of PCA, principal components (PCs) satisfying the requirement (accumulative contribution rate is above 85\%) of PCA in this correlation coefficient 
matrix are received [14]. Eigenvalues and eigenvectors of every PC are as follows (Table 4):

In accordance with Table 4, the first four accumulative contribution rates (ACRs) of PCs have achieved $89.47 \%$. Namely, they have included $89.47 \%$ information of original data. Therefore, performance of a company would be fully evaluated by choosing first four PCs. The linear equations are as follows:

$$
\begin{aligned}
& Y_{1}=0.56 x_{1}+0.46 x_{2}+0.555 x_{3}+0.246 x_{4}+0.313 x_{5} \\
& Y_{2}=-0.131 x_{1}-0.358 x_{2}-0.222 x_{3}+0.69 x_{4}+0.574 x_{5} \\
& Y_{3}=-0.034 x_{1}-0.066 x_{2}-0.014 x_{3}-0.664 x_{4}+0.744 x_{5} \\
& Y_{4}=-0.428 x_{1}+0.808 x_{2}-0.367 x_{3}+0.104 x_{4}+0.139 x_{5}
\end{aligned}
$$

However, in this case, we are focusing on operating performance and market performance which are part of the performance of a company. Business performance also includes financing capacity, debt paying ability, capital structure and so on that also can be manifested by these five nominated indicators.

Therefore, first two PCs whose ACR has been closed to $60 \%$ are optimal to explain the influence of these indicators demonstrating sample enterprises' operating performances and market performances. Here is the economic interpretation of first two PCs:

In the first PC $\left(\mathbf{y}_{1}\right)$, coefficients of the first three indicators are relatively larger and of little difference. Meanwhile, these three indicators are on behalf of operating performance as introduced previously. The larger value of this PC, the better this company performed. Besides, projections of indicators on the abscissa indicate the internal relations between these indicators and operating performance.

In the second PC $\left(\mathbf{y}_{2}\right)$, the 4th and 5th coefficients are absolutely larger than the others. Meanwhile, these two indicators are on behalf of market performance as introduced previously. Likewise, the larger value of this PC, the better this company performed. Additionally, projections of indicators on the ordinate can tell the internal relations between these indicators and market performance.

Figure 4 and Figure 5 detailedly illustrate how these five indicators varied from non VC-backed enterprises to VC-backed enterprises in the coordinate consisted of operating performance and market performance.

Where the abscissa stands for operating performance and the ordinate indicates market performance. Projections of indicators on each axis illustrate the internal relations between these indicators and the corresponding principal components.

As shown in Figure 4 and Figure 5, we can realize OROA, OCFROA and Sample $\mathrm{Q}$ are of most relations with operating performance both for non $\mathrm{VC}$ - and $\mathrm{VC}$-backed companies. Meanwhile, WR and MC take the ultimate liability for market performance.

As to the variations of indicators, on the one hand, influences of OROA and OCFROA are obviously affected by $-10 \%$ and $-5 \%$ along with the participation of venture capital. Meanwhile, Sample $\mathrm{Q}$ has a slight growth by $+6 \%$. As a result, non VC-backed companies' operating performance is superior to that of VC-backed companies.

On the other hand, never does WR reveal any difference between VC- and non VC-backed firms. With the reduction of MC from $63 \%$ to $57 \%$, VC-backed companies suffer an inferior market performance to non VC-backed companies. 


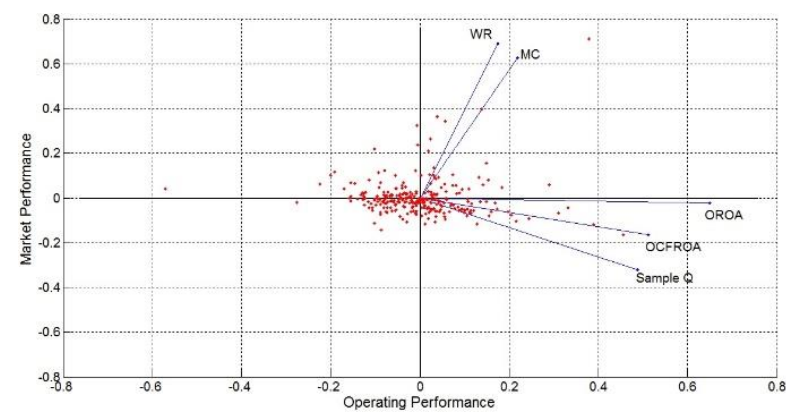

Figure 4. PCA of Non VC-backed Enterprises

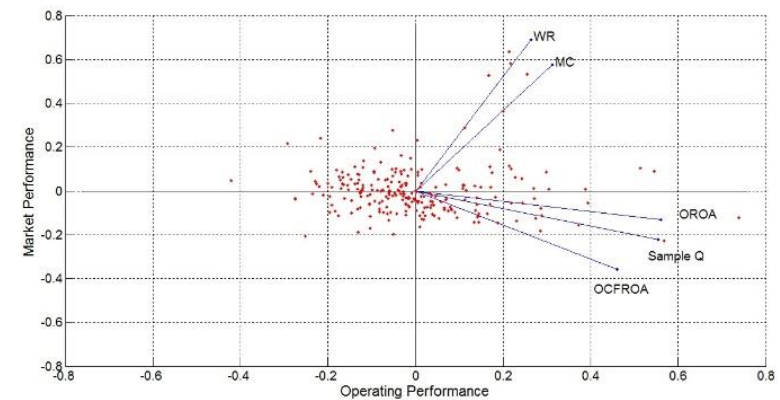

Figure 5. PCA of VC-Backed Enterprises

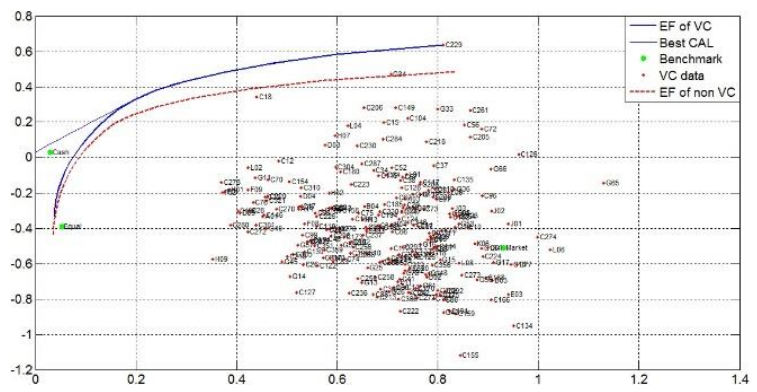

Figure 6. Efficient Frontier of VC-Backed Enterprises

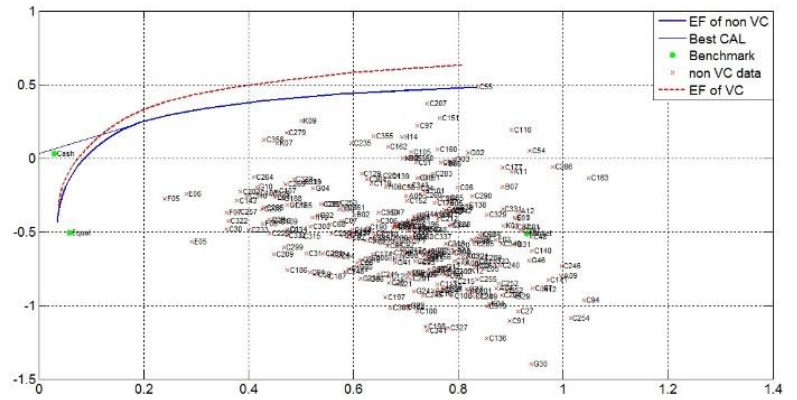

Figure 7. Efficient Frontier of Non VC-backed Enterprises

\subsection{Mean Variance Analysis of Returns on Invested Enterprises}

In this case, we have collected continuous closing prices from the dates of every sample company's IPO to their 700th trading day. Based on mean variance analysis, we have solved daily means of returns, standard deviations and covariances of VCand non VC-backed companies respectively during the sample period, and have drawn two efficient frontier curves for each group meanwhile (Figure 6 \& Figure 7). 
The efficient frontier curves demonstrate the optimal mean returns of portfolios constituted by VC- and non VC-backed enterprises for a given standard deviation of returns. Table 5 exhibits the comparisons of concrete data from the figures above:

Table 5. Comparisons of Returns for a Certain Risk

\begin{tabular}{ccc}
\hline Volatility & Mean of Returns (VC) & Mean of Returns (non VC) \\
\hline 0.15 & 0.241 & 0.175 \\
0.25 & 0.389 & 0.294 \\
0.35 & 0.465 & 0.353 \\
0.45 & 0.519 & 0.395 \\
0.55 & 0.563 & 0.431 \\
0.65 & 0.596 & 0.377 \\
0.75 & 0.620 & 0.435 \\
\hline
\end{tabular}

From visualized figures and table above, it can be realized returns on VC-backed enterprises are higher than those on non VC-backed enterprises for a same level of risk.

In the same way, risks on companies with influence of venture capitals are better controlled than those without the influence for a certain return.

Up to this point, we have confirmed the significance of venture capitals on controlling harmful volatility of share prices, and monitoring business risks which would be building up investors' confidence effectively as well.

\section{Conclusion}

By analyzing corporate post-issuing performance of a sample of 280 non VCbacked companies and 236 VC-backed companies that have listed in Chinese stock markets from 2008 to 2010 , this paper finally draws a simple but comprehensive result which is opposite to the mainstream concept. On the one hand, comparing with non VC-backed companies, companies supported by venture capitalists underperformed apparently both in operating performance and market performance. Neither has this conclusion been drawn in China nor in any other developing countries before. On the other hand, the research outcome of volatility illustrates positive effects of venture capitals on weakening the risk of investing in a business in Chinese stock markets in a period of three years.

Just as expected, although venture capitals are unable to enhance aftermarket performance of Chinese businesses, they still stand for the "guaranteed assets creators [15]" to the public.

Combining advantages and disadvantages brought by venture capitals, here is the explanation of this situation. Venture capitals are the sponsors of invested companies before the start-ups successfully reach their milestones and their future financing can be guaranteed [16]. Moreover, venture capitals normally work in the capacity of "coaches" to ensure that their invested enterprises are on the right track from the domain of personnel changes to strategies shifting. Nevertheless, seeking a way with high-efficiency to withdraw funds for their own benefits is the highest priority of venture capitalists that blinds them to the sustainable development of their invested companies. Therefore, a VC-backed company with an excellent and low-risk return on equity but unsatisfying operating performance and market performance is reasonable.

It is worth noting that, with an excellent performance of the share price, it would be easier to attract prestigious shareholders with industrial resource and a horizon of development that will tremendously promote an enterprise's sustainable 
development. In addition, from experimental results of this paper, multi-choices have been provided for Chinese companies in different industries to discover what they need for sustainability and select suitable developing paths for business while taking advantages and conditions into consideration.

\section{References}

[1] 2013 China Venture Capital Yearbook, China Venture Capital Research Institute, Beijing, China, (in Chinese), no. 94, (2013).

[2] 2013 China Venture Capital Yearbook, China Venture Capital Research Institute, Beijing, China, (in Chinese), (2013), pp. 826-893.

[3] H. Abdi and L .J. Williams, "Principal component analysis", WIREs Comp Stat, (2010), pp. 433-459.

[4] C. Fischer, "Why Do Companies Go Public?", Empirical Evidence from Germany's Neuer Markt, Available online: http:// papers. ssrn.com/sol3/papers. cfm? Abstract_id=229529, (2000).

[5] S. A. Franzke, "Underpricing of Venture-Backed and Non Venture-Backed IPOs: Germany' Neuer Market", Essex Finance Centre Discussion, (2004).

[6] E. B. Lindenberg and S. A. Ross, "Tobin's q Ratio and Industrial Organization”, Journal of Business, vol. $54,(1981)$, pp. 1-32.

[7] L. H. P. Lang, R. M. Stulz and R. A. Walkling, "Managerial performance, Tobin's Q and the gains from successful tender offers", Journal of Financial Economics, vol. 24, (1989), pp. 137-154.

[8] K. H. Chung and S. Pruitt, "A simple Approximation of Tobin's q", Financial Management, vol. 23, (1994), pp. 70-74.

[9] J. R. Ritter, "The Long-Run Performance of initial Public Offerings", The Journal of Finance, vol. 46, (1991), pp. 3-27.

[10] A. Brav and P. A. Gompers, "Myth or Reality? The Long-Run Underperformance of Initial Public Offerings: Evidence from Venture and Nonventure Capital-Backed Companies", The Journal of Finance, vol. 52, (1997), pp. 1791-1821.

[11] L. F. Niu, R. Z. Zhou, X. Zhao and Y.Shi, "Two New Decomposition Algorithms for Training BoundConstrained Support Vector Machines", Foundations of Computing and Decision Sciences, vol. 39, (2015), pp. 67-86.

[12] N. M. Vaxevanidis, J. D. Kechagias, N. A. Fountas and D. E.Manolakos, "Three component cutting force system modeling and optimization in turning of AISI D6 tool steel using design of experiments and neural networks", Available online: http: //www. docin.com/p-705595095.html, (2013).

[13] Z. H. Sun and J. Yearwood, "Handbook of Research on Demand-Driven Web Services: Theory, Technologies, and Applications", 1st ed.; IGI Global: PA, USA, (2014), pp. 411-412.

[14] Y. X. He, "Methods and Applications of Comprehensive Electric Power Evaluation, 1st ed.; China Electric Power Press, Beijing, China, (in Chinese), (2011), pp. 185-186.

[15] C. B. Barry, C. J. Muscarella, J. W. Peavy and M. R. Vetsuypens, "The role of Venture Capital in the creation of Public Companies: Evidence from the going-public process", Journal of Financial Economics, vol. 27, (1990), pp. 447-471.

[16] P. Gompers and J. Lerner, "The Venture Capital Revolution”, Journal of Economic Perspectives, vol. 15, (2001), pp. 145-168. 